\author{
Alla Anisimova, Mariia Dobrushyna, Nataliia Safonova \\ Oles Honchar Dnipro National University, Ukraine
}

\title{
SEMANTIC PECULIARITIES OF THE CONCEPT LANGUAGE POLICY IN A MULTILINGUAL ASPECT
}

\begin{abstract}
The article deals with the issues where linguistic the concept of LANGUAGE POLICY is revealed on both regional and international levels. It covers the description of LANGUAGE POLICY and some aspects of its influence on the process of development Ukrainia society in a multilingual aspect. It is emphasized that LANGUAGE POLICY has become a widespread phenomenon in modern society. Learning a linguistic situation in a given society can be considered an important means of forming the ability to conduct intercultural dialogues. The correlation the features of the phenomenon LANGUAGE POLICY in different countries helps to outline their national specific features, which contribute to a deeper understanding of both the foreign and the native language and culture. Any linguistic system is open and fairly stable. As for the methods and learning tools, they can vary depending on the applicable learning concept. The article gives a detailed description of the development of the function and the peculiarities of the meaning of the concept LANGUAGE POLICY on the contemporary level of the sociolinguistic development of the society on the basis such countries as the USA, France, Germany, Poland, Ukraine. It uses the definition of the concept as a mental formation, which includes the knowledge and experience of a person.
\end{abstract}

Keywords: LANGUAGE POLICY, concept, sociolinguistic, multilingualism, society, cognitive linguistics, European Union (EU), globalization.

\section{Introduction}

The globalization and internationalization of the society presupposes the development of all the layers of the society. Language is one of the phenomena that undergoes such changes. This fact prompts the necessity to study the concept LANGUAGE POLICY. LANGUAGE POLICY has gained major importance. A lot of documents with this aspect have appeared. These documents regulate LANGUAGE POLICY both on the regional and on the state level, that is the term LANGUAGE POLICY has entered the usage not only on the level of the government, but also on the regional level within one state or territory.

The actuality of this research is in the fact that there are some changes in the semantic 
structure of the concept LANGUAGE POLICY and its associations that are in the mind of people depending on the nation these people represent.

The aim of the article is to study the function and the peculiarities of the meaning

\section{Theoretical background}

The research of concepts belongs to one of the major fields of linguistics - cognitive linguistics. Language as a sphere of cognitive linguistics, is the field that studies the interaction between the human brain, mentality and cognitive processes. A. Veragen states that the key principle of cognitive linguistics is the fact that semantics is cognitive, and it does not raise the problem of the relations between the language and the world [19].

One of the fundamental principles of understanding the cognitive science is to comprehend categories and categorization. Categorization allows you to systematize common and different features of one and the same phenomenon.

According to O. Kubryakova, the concept is a mental or psychological unit in our consciousness, informative structures that depict people's knowledge and experience, an operative significant unit of knowledge, mental lexicon, the conceptual system and lingua mentalis of the worldview reflected in human's psychics [24, p. 89-90]. A concept of the concept LANGUAGE POLICY on the contemporary level of the sociolinguistic development of the society on the basis such countries as the USA, France, Germany, Poland, Ukraine.

includes not only notional-differentional, but also conotative, imaginative, evaluative, social characteristics, and all of them should taken into consideration when describing the concept [21].

In our research we will use the following definition which is based on the two previous ones, proposed by V. Maslova. According to her, the concept is an operative significant unit of memory, a mental lexicon, a conceptual system, and brain language reflected in human's psychics [25, p. 31].

Summing up the above said, we can confirm that in our work by the concept we understand a mental unit, which includes knowledge and people's experience, that is formed in the process of acquiring the worldview.

Nowadays, public administration policy in many countries is aimed at rapid integration into the global space. Communities belonging to the Western world have made a noticeable shift in this direction by changing the way where LANGUAGE POLICY was understood as a politics 
focused not only on a single, state language, but also on the point that national minority languages are now also taken into account [13]. The European researchers $[1 ; 10 ; 20]$ dedicated their works to LANGUAGE POLICY and multilingualism as an integral part of LANGUAGE POLICY where multilingualism is recognized as part of European policy. As the EU adheres to the principles of multilingualism and fundamental rights to non-discrimination and the equality of its citizens, these principles imply equal rights to all citizens to have legal documents in their national languages [10]. There are 24 officially recognized languages in the EU [4], more than 60 indigenous regional and minority languages, and many non-indigenous languages spoken by migrant communities It is noted that the $\mathrm{EU}$ has limited influence because education and language policies are the responsibility of each Member State, but in view of such diversity, the EU is obliged to protect this linguistic diversity and to promote the knowledge of languages for reasons of cultural identity and social integration and cohesion, and because multilinguals are better able to use the economic, educational and professional opportunities created by an integrated Europe [15]. Thus, we can distinguish the following lexical units that aret the verbalizers of LANGUAGE POLICY: official language, indigenous regional language, minority language, linguistic diversity, cultural identity, social integration, cohesion, integrated Europe, multilingualism

It is necessary to outline the term "language" as it is defined in the official documents. In 1998, the document "The Oslo Recommendations regarding the Linguistic Rights of National Minorities" defined the term "language" as a private matter closely linked to identity, but at the same time it is stated that language is an important tool for social organization of society, which in many situations becomes the subject of public interest [16]. Also, language is defined as code with various forms (written, spoken, standard, non-standard), functions (usually expressed in terms of territory and public status within the state system), and values (as a means of exchange, with specific material and non-material qualities) $[14$, c. 8-9].

Lexical identifiers of the concept LANGUAGE, considered in terms of "Oslo recommendations": a tool for organizing society, a private issue, a subject of public interest.

Rapid globalization often leads to discussions about the use of a language in a particular territory. From time to time this issue is not used only in national scope, but also has a profound effect on the geopolitical situation in the entire region. That is why LANGUAGE POLICY debates are always 
more than those of just language use debates. Understanding the political, economic, and social theory can provide researchers with appropriate tools how to explain what is important, why it is important, and how certain strategies or policy approaches may influence (or may not) influence on such

\section{Methods}

Having conducted the research in terms of verbalizers of the concept LANGUAGE POLICY within lexicographical sources and documents in the European and Ukrainian discourses the definitions of the lexical unit LANGUAGE POLICY have been selected.

Comparing data obtained from the English $[8,11]$ and Ukrainian lexicographic sources $[26,22]$, we can note the following. So, most definitions are given in the Ukrainian lexicographic sources. Such definitions are fixed both in dictionaries and in scientific works. As for the English lexicographic sources, the basic definitions are given precisely in scientific works. It should be emphasized that all lexicalsemantic variants enlarge each other.

Nowadays, among the definitions of the concept LANGUAGE POLICY, we can draw attention to the definition given by N. Labrie who defines LANGUAGE POLICY as the exercise of social control over linguistic pluralism and variation, using political methods, including the expression of the debate in their LANGUAGE POLICY and planning research [14, c. 9]. It is noted that for states with different societies, a balanced LANGUAGE POLICY should be understood as an indispensable element that supports cohesion within the state and ensures regional security [18, p. 4].

balance of power in society and the codification of linguistic practices by agents loaded with power [11]. Analysis of the semantic structure of the lexical unit LANGUAGE POLICY allows explaining the concept implementation by such lexical units as social control, linguistic pluralism, the balance of power in society, codification of language practices.

The following definition given by R. B. Kaplan [8] states that LANGUAGE POLICY is a set of ideas, laws, rules and practices aimed at achieving planned changes in the language of a society, group, or system interprets the concept LANGUAGE POLICY using the following lexical units: $a$ set of ideas, laws, rules and practices, planned changes.

The next definition, that can be considered,is the definition provided by $\mathrm{J}$. Crawford. According to him, a LANGUAGE POLICY is defined as: firstly, what government does officially - through legislation, court decisions, executive action, 
or other means - to (a) determine how languages are used in public contexts, (b) cultivate language skills needed to meet national goals, or (c) establish the rights of individuals or groups to learn, use, and maintain languages.Secondly, by language policy it is understood the government regulation of one's own language use, including steps to promote clear communication, train and recruit personnel, guarantee due process, foster political participation, and provide access to public services, proceedings, and documents [3].Considering this we may point out the verbalizers of the concept LANGUAGE POLICY are the following lexical units: official power, legislation, judgments, enforcement actions, public context, language teachers, national priorities, rights of pindividuals, right of group, languages.

Having analyzed the Ukrainian lexicographic sources $[26,22]$, we can give the following definition of LANGUAGE POLICY in the Ukrainian discourse: LANGUAGE POLICY (language politics [26, p. 448], LANGUAGE POLICY [7; 8]) is a concentrated expression of the ideological and social principles that determine the political and practical attitude of a state system (authorities) to functioning, development. and the interaction of languages, to their role in the life of people or peoples, which is implemented in a combination of ideological, political, legal, administrative deeds aimed at the development, functioning, balance of languages, change or preservation of the linguistic situation in the state, regions, society [26, c . 445-446]. Analyzing the semantic structure of the lexical unit LANGUAGE POLICY, it is established that the implementation of the concept LANGUAGE POLICY within the given definition is explained by the following lexical units: ideological, social principles, development and interaction of languages, set of political, administrative, ideological, developmental, ideological, languages, language situation.

The following definition is given by B. Brycyn where he defines LANGUAGE POLICY as a set of ideological postulates and practical actions aimed at regulating language relations in the country or developing the language system in a particular direction [22]. The semantic structure of the lexical unit LANGUAGE POLICY within this definition is explicated by the following lexical units: set of ideological postulates, set of parctic actions, regulation of linguistic relations, development of language system. State regulations of one's own language use, including steps to facilitate clear communication, training and recruitment, promote political participation, and provide access to public services, justice and documents. 


\section{Results and discussions}

The analysis of political and legal sources shows that LANGUAGE POLICY regulates and regulates the principles of using state, official, titular language and language of national minorities [26, p. 446]

In order to analyze further verbalization of the concept LANGUAGE POLICY, it is necessary to mention the concepts that accompany the lexical unit LANGUAGE POLICY in legal and political sources. Thus, in 1953 UNESCO distinguished between "national" and "official" language in the publication "The Use of Vernacular Languages in Education". So, the national language is a language of political, social and cultural unity. Official language - the language used in activities related to public administration: in the legislative, executive and judicial spheres $[17$, p. 46]. Thus, the national language is a language that performs an integrative function within a given state, and also is a symbol of a particular state, and the official language is the language of public administration, legislation, judiciary [26, p. 446]. According to V. Zabolotsky, the basic definitions of "national language" and "official language" in the basic laws (of Ukraine) are fixed as identical [23, p. 7-8].

The next lexical unit to be considered in the context of the concept under study is the "titular language". O. Selivanova defines the titular language as a language which name corresponds to the name of an ethnic, state or national-territorial unity $[26$, p. 446]. The language of national minorities is defined as the language of the non-dominant ethnic group and, on the other hand, to other groups in the country. Such an ethnic group is aware of its own ethnic identity, demonstrating a sense of solidarity aimed at preserving its culture, traditions and language [26, p. 446].

LANGUAGE POLICY and planning as a separate discipline is distinguished within the framework of applied linguistics [5, p. 82] The component of LANGUAGE POLICY is language planning, which is defined as the implementation of LANGUAGE POLICY, a set of measures that affect the functionality of the language [27]. Language planning is carried out by commissions of state bodies, academies, universities [26, p. 446]. For the first time the term "language planning" was used in the article "Language Planning in Modern Norway" by E. Haugen, where by "language planning" the researcher understood activities aimed at normalizing the spelling, grammar and vocabulary of spoken and written speech in a heterogeneous language environment [6, p. 109]. Language planning is an activity undertaken by the government (potentially involving largescale changes in the society) that promotes systemic language change in some language communities. The reasons for this change lie 
in structures developed by the government aimed at supporting civil order and communication, as well as moving the entire society in a particular direction that the government considers to be "good" or "useful". The introduction of language planning leads to the adoption of LANGUAGE POLICY by the government (or other authoritative body or person) $[8$, p. 2]. The field of LANGUAGE POLICY and planning research was formed in the early 1960s by linguists who were interested in addressing the language problems of new, developing and / or post-colonial countries $[5$, p. 82].

O. Selivanova also defines a certain sequence of actions that is provided by language planning. Firstly, attention must be paid to the sociolinguistic studies of the linguistic situation in the country or in the region. Secondly, there must be defined the goals and steps of language planning (choice of national language or languages, determination of attitudes towards national minority languages, standardization and codification of literary language, choice of alphabet) must be defined. Thirdly, there should be conducted the modernization of the language (spelling. Terminological systems and functional styles, adaptation of words of foreign origin). In the fourth stage, the preparation of textbooks, dictionaries as well as, the training of philological specialists and journalists should be organized [26, p. 447].

LANGUAGE POLICY is a very complex issue; thus, LANGUAGE POLICY, as a separate field of study, requires an interdisciplinary approach that relies on the knowledge and tools of a range of disciplines, such as applied linguistics, sociolinguistics, sociology, anthropology, and political theory [9].

LANGUAGE POLICY and planning research should be understood as multidisciplinary and interdisciplinary, as conceptual and methodological tools for disciplines integrated and applied in real language problems and tasks, which by definition are embedded in all aspects of society and social life [14, p. 9].

A. Karoly notes that, often, LANGUAGE POLICY and "language planning" are interchangeable. The researcher determines that the term LANGUAGE POLICY should be considered in its broadest sense, since LANGUAGE POLICY is based on an implicit linguistic ideological framework that is associated with broad political and social ideologies [9]. In the European context, there are four main categories established on the basis of political recognition of languages: national / official languages, minority languages - which in their turn can be divided into old and new minority languages.

Having analyzed lexicographical sources as well as researchers' definitions of the 
concept LANGUAGE POLICY considering the European discourse and the Unkrainian one, we can present the following field structure (Pic.1):

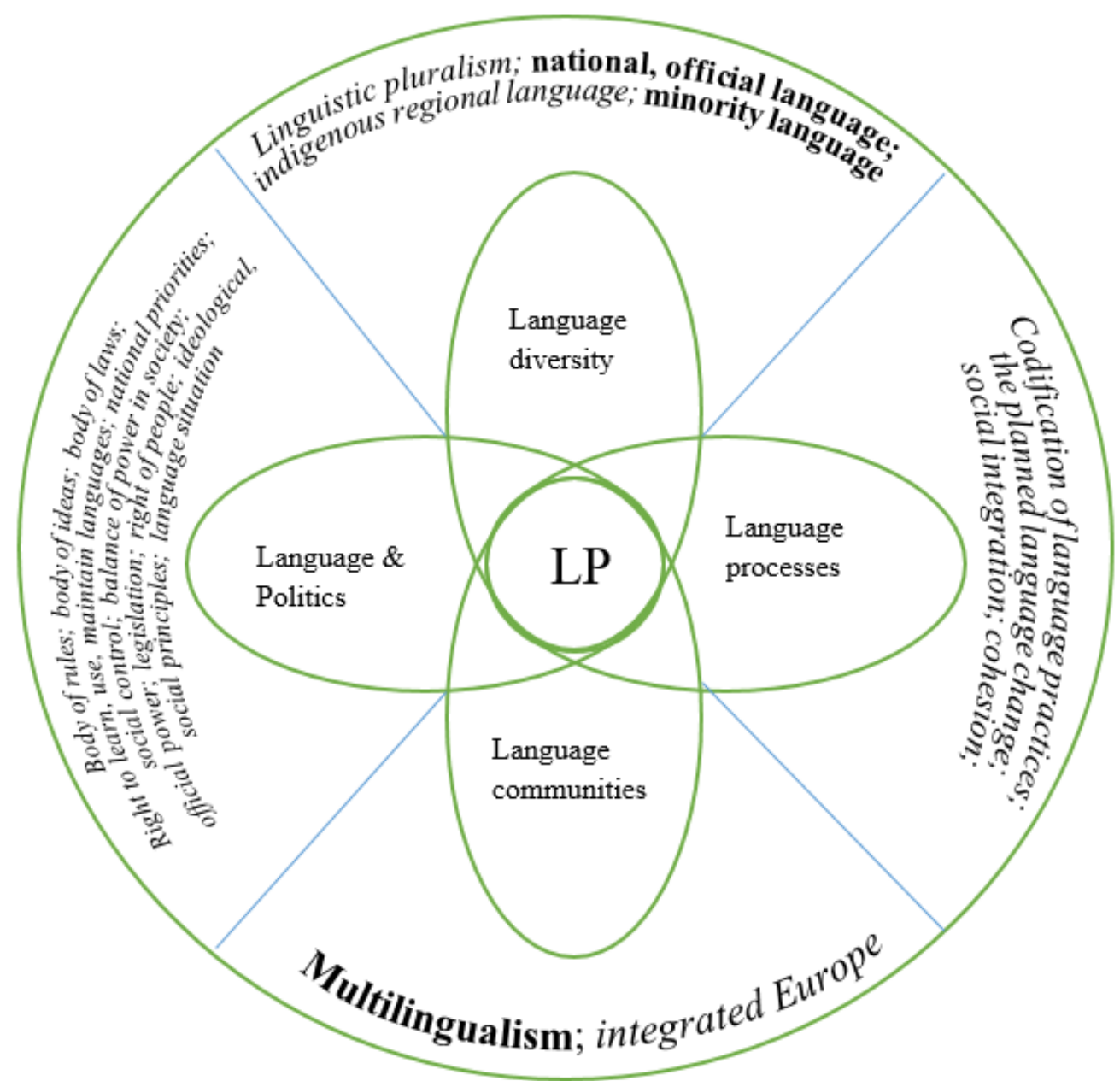

Pic. 1

\section{Conclusions}

The results of the study, conducted on the basis of the analysis of scientific papers and official documents and references will be schematically reproduced with the help of the field structure of the concept, because in our opinion it is this structure that makes it possible to generalize a large number of lexical units, to group lexical units and show them more clearly than a frame one.

Thus, having analyzed the works of the scholars of various fields, such as linguistics $[9,12]$, sociolinguistics [12], as well as documents considering LANGUAGE POLICY in the European discourse we may say that according to Special Eurobarometer 386 [15], Consolidated Version of The Treaty On The Functioning Of The European Union [2] documents, we can schematically reproduce the field structure of the concept LANGUAGE POLICY as follows (Pic. 2): 


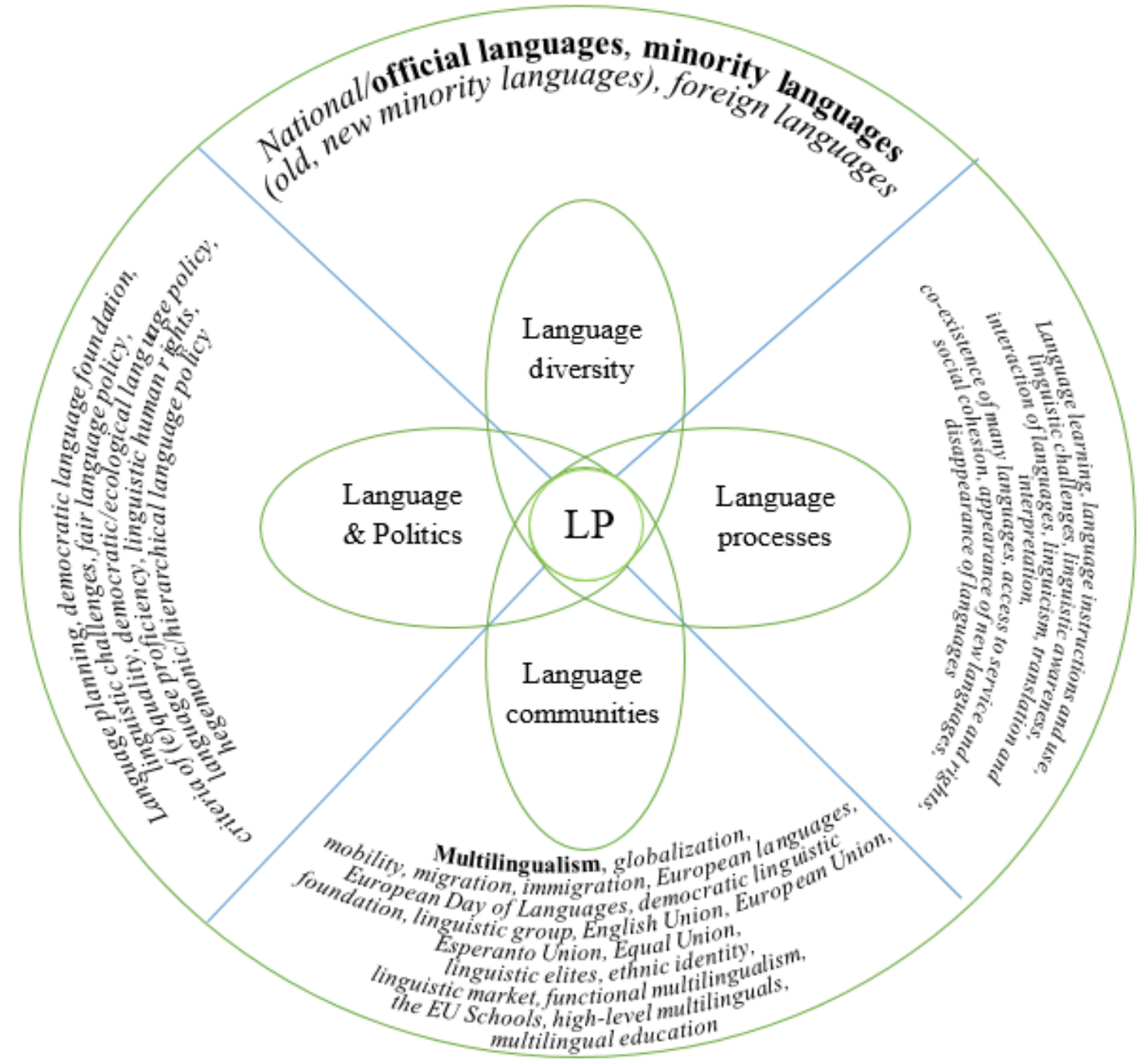

Pic. 2

As far as we can see, there are a lot of similarities (in bold) in verbalization as well as differences (in italics) between them. It is shown that there are more differences than similiarities: among the lexical units that are united under the common feature Language diversity there are only three of them that are represented in both structures: national, official language and minority language, whereas other features (linguistic pluralism; indigenous minority language; old, new minority languages; foreign languages) vary. Having considered common feature
Language process one can say that there is nothing in common, because in the picture 2 we may found out more in-depth information considering language and its processes (codification of language practice; the planned language change; language learning, language instructions and use, linguistic challenges, linguistic awareness, interaction of languages, linguicism, translation and interpretation, co-existence of many languages, access to service and rights, social cohesion, appearance of new languages, disappearance of languages). 
The same goes for Language\&Politics feature: there is nothing in common between lexicographic sources and documentary explanation (body of rules; body of ideas; body of laws; right to learn, use, maintain languages; national priorities; social control; balance of power in society; official power; legislation; right of people; ideological, social principles; language situation; language planning, democratic language foundation, linguistic challenges, fair language policy, criteria of (e)quality, democratic/ecological language policy, language proficiency, linguistic human rights, hegemonic/hierarchical language policy). Common feature Language community has just one shared lexical unit multilingualism (globalization, mobility, migration, immigration, European languages, European Day of Languages, democratic linguistic foundation, linguistic group, English Union, European Union, Esperanto Union, Equal Union, linguistic elites, ethnic identity, linguistic market, functional multilingualism, the EU Schools, high-level multilinguals, multilingual education are not found in the picture 1). It can be explained by the fact that defining the concept itself scholars use the accurate vocabulary of the linguistically developed society with the strong view on the multilingualism in order to depict the notion clearly and precisely, whereas numerous documents explain the given concept by the means of more extensive vocabulary to give sufficiently detailed information about the lexical unit under the study.

To sum up, we note that in this study we have focused on the approaches and methods of exploring concepts as objects of cognitive linguistics. In the study we used the definition of the concept as a mental formation, which includes the knowledge and experience of a person. The concept analysis was conducted on the basis of both Ukrainian and English lexicographic sources. The field structure has been built. We see that the semantic structure of the concept under study is polysemantic. Analyzing the set of values allows us to reveal the field structure of the concept LANGUAGE POLICY in modern Ukrainian and modern English. We have explored that definitions complement each other in explaining the phenomenon of LANGUAGE POLICY, while the documents detail the definitions both quantitatively and qualitatively. 


\section{References}

1. Adler A. Languages and language policies in Germany / A. Adler, R.Beyer // National language institutions and national languages. Contributions to the EFNIL Conference 2017 in Mannheim. - Budapest : Hungarian Academy of Sciences, 2018. - P. 221-242.

2. Consolidated version of the Treaty on the Functioning of the European Union http://data.europa.eu/eli/treaty/tfeu_2012/oj.

3. Crawford, J. W. (2006) Language policy. Retrieved from http://www.languagepolicy.net/archives/langpol.htm

4. European Commission (2013) Мемо of 26.09.2013 Frequently asked questions on languages in Europe https://europa.eu/rapid/press-release_MEMO-13-825_en.htm

5. Goundar Pr. TheCharacteristicsofLanguagePolicyandPlanning Research:

6. Haugen E. Planning for a Standard Language in Modern Norway Anthropological LinguisticsVol. 35, No. 1/4, A Retrospective of the Journal Anthropological Linguistics: Selected Papers, 1959-1985 (1993), pp. 109-123

7. Johnson D.C. What is language policy? In: Language Policy. Research and Practice in Applied Linguistics. London, Palgrave Macmillan, 2013.

8. Kaplan, R.B., \& Baldauf, R.B. (1997). Language Planning from Practice to Theory. Multilingual Matters.

9. Károly A. Language Policy in the European Union // Eger Journal of English Studies VIII, 2008. - P. 125-141.

10. Kużelewska E. Unity in Diversity. The Language Policy of the European Union. TUDIES IN LOGIC, GRAMMAR AND RHETORIC 38 (51) 2014

11. Labrie, N. Globalisation and management of linguistic pluralism in Europe. - Symposium for Cultural Diversity and the Construction of Europe, Barcelona. - 14-16 December, 2000.

12. LangackerR.W. LinguisticConstrualandConceptualAnalysis. UniversityofCalifornia, SanDiego

13. Norrby C., Hajek J. UniformityandDiversityinLanguagePolicy: GlobalPerspectives. Multilingual Matters, 2011. - 312 p.

14. Ricento T. An Introduction to Language Policy: Theory and Method. - Oxford: Blackwell, 2006. - 371 p.

15. Special Eurobarometer $386:$ Europeans their 
languageshttp://ec.europa.eu/public_opinion/archives/eb_special_399_380_en.htm\#386

16. The Oslo Recommendations regarding the Linguistic Rights of National Minorities \& Explanatory Note, 1998[Електроннийресурс]. - Режим доступу https://www.osce.org/hcnm/oslo-recommendations?download=true Дата звернення: 14.11.2019

17. The Use of vernacular languages in education https://unesdoc.unesco.org/ ark:/48223/pf0000002897

18. Ulasiuk I. Language Policy and Conflict Prevention. - Brill|Nijhoff, 2018. - 310.

19. Verhagen A.ConstrualandPerspectivization// The Oxford Handbook of Cognitive Linguistics, 2010.

20. Vicente F.C. Brief considerations about language policy: An European Assessment / F.C. Vicente, P.C. Vicente // Language Documentation \& Conservation Special Publication No. 9 (January 2016): Language Documentation and Conservation in Europe. - pp. 185-190

21. Боярская Е.Л. Категоризация как базовая когнитивная процедура // Вестник Балтийского федерального университета им. И. Канта, 2011. - Вып. 2. - С. 18-28

22. Брицин В.М. Мовна політика // Українська мова. Енциклопедія - К.: «Українська енциклопедія» ім. М.П. Бажана, 2000. - С. 328-332.

23. Заблоцький В.В. Мовна політика в Україні: стан та напрями оптимізації : автореф. дис. канд. політ. наук : спец. 23.00.02 «Політичні інститути та процеси (політичні науки)» / В.В. Заблоцький. - Х., 2007. - 16 с.

24. Кубрякова Е.С. Концепт // Кубрякова Е.С., Демьянков В.З. и др. Краткий словарь когнитивных терминов. - М., изд-во МГУ, $1996 .$,

25. Маслова В. А.Когнитивная лингвистика: Учебное пособие / В. А. Маслова. -Мн.: ТетраСистемс, 2004. - 256 с.

26. Селіванова О.О. Лінгвістична енциклопедія / О.О. Селіванова. - П.:Довкілля-К, 2011. $-844 \mathrm{c}$.

27. Чередник Ю. Мовне планування як складова мовної політики держави / Ю. Чередник /// Стратегія регіонального розвитку: формування та механізми реалізації : матеріали підсумкової наук.-практ. конф. за міжнародною участю, 31 жовт. 2009 р. - О. : ОРІДУ НАДУ, 2009. - С. $371-373$. 